\title{
PENGARUH DISIPLIN, BUDAYA KERJA, DAN MOTIVASI TERHADAP KEPUASAN KERJA PEGAWAI PADA FAKULTAS EKONOMI UNIVERSITAS PGRI PALEMBANG
}

\author{
Totok Sudiyanto *)
}

\begin{abstract}
ASTRAK
Tujuan penelitian ini adalah untuk mengetahui dan membuktikan pengaruh disiplin, budaya kerja, motivasi secara simultan maupun secara terhadap kepuasan Kerja pegawai pada Fakultas Ekonomi Universitas PGRI Palembang. Populasi dalam penelitian ini adalah seluruh pegawai yang ada di Fakultas Ekonomi Universitas PGRI Palembang sebanyak 33 orang dan sekaligus diambil sebagai sampel. Teknik analisis yang digunakan adalah analisis regresi berganda dilanjutkan dengan uji hipotesis menggunakan uji $\mathrm{F}$ dan uji t.

Hasil penelitian menunjukkan bahwa Secara bersama-sama atau simultan terdapat pengaruh yang positif dan signifikan disiplin kerja, budaya kerja dan motivasi terhadap kepuasan kerja pegawai dan secara parsial terdapat pengaruh yang positif dan signifikan disiplin kerja, budaya kerja dan motivasi terhadap kepuasan kerja pegawai Pada Fakultas Ekonomi Universitas PGRI Palembanghal ini berarti apabila ada peningkatan dalam disiplin kerja, budaya kerja dan motivasi maka kepuasan kerja pegawai akan meningkat.
\end{abstract}

Kata kunci : Disiplin, budaya kerja, motivasi dan kepuasan kerja

\section{PENDAHULUAN}

\section{A. Latar Belakang}

Sumber Daya Manusia (SDM)

pada hakikatnya merupakan aset utama dan bagian integral dari suatu organisasi maupun perusahaan. Sumber daya manusia yang berkualitas merupakan hal yang penting bagi kelangsungan hidup organisasi, sedangkan manajemen yang efektif adalah kunci bagi keberhasilan suatu organisasi tersebut. Salah satu dari profesionalitas SDM adalah mampu bekerja dengan baik. Jika organisasi ingin berkembang dengan pesat, maka organisasi harus mempunyai sumber daya manusia yang mampu menampilkan kinerja yang baik.

"Kedisiplinan adalah kesadaran dan kesediaan seseorang mentaati peraturan perusahaan dan normanorma sosial yang berlaku". Kedisiplinan tidak datang dengan sendirinya tanpa adanya kemauan dari dalam diri pegawai itu sendiri, dan dorongan dari pihak perusahaan melalui penegakkan kedisiplinan yang dituangkan dalam peraturan
perusahaan.

Budaya kerja merupakan salah satu elemen kunci pengelolaan sumber daya manusia yang menentukan keberhasilan dan kehancuran suatu organisasi, Sulaksono (2002 : 114). Sejalan dengan itu, Kementerian Pendayagunaan Aparatur Negara telah mengembangkan program yang menyangkut budaya kerja aparatur yang tertuang dalam Keputusan Menteri Pendayagunaan Aparatur Negara Nomor 25/KEP/M.PAN/4/2002 tentang Pedoman Pengembangan Budaya Kerja Aparatur Negara, yang di dalamnya terdapat 17 (tujuh belas) pasang nilai-nilai dasar budaya kerja, yang semuanya diarahkan pada terwujudnya pemerintahan yang baik. Aparatur Negara yang mampu memahami dan memiliki semangat dan etos kerja yang bertanggungjawab, bermoral, berdisiplin, profesional dan produktif akan mempercepat terwujudnya pemerintahan yang baik.

Begitu pula ada salah satu faktor juga yang dianggap penting bagi peningkatan kinerja yaitu motivasi 
pegawai. Motivasi kerja adalah jiwa pendorong yang kuat bagi manusia untuk melakukan suatu pekerjaan yang berkaitan dengan tujuan dan kebutuhan yang ingin dicapainya. Hal tersebut sejalan dengan pengertian motivasi sebagaimana diungkapkan oleh Hasibuan (2006:143), "Penggerak (motivating) adalah pemberian daya penggerak yang menciptakan kegairahan kerja seseorang agar mereka mau bekerja sama, bekerja efektif dan terintegrasikan dengan segala daya upayanya untuk mencapai kepuasan".

Bertitik tolak dari pendapat di atas, terlihat akan pentingnya motivasi kerja dalam rangka mendorong manusia yang ada dalam perusahaan, agar mereka terdorong untuk mengaktualisasikan segala kemampuan yang dimilikinya dalam rangka pencapaian tujuan perusahaan.

Universitas PGRI Palembang sebagai salah satu universitas yang bergerak dibidang pendidikan. Dalam rangka menghadapi tantangan dan tugas-tugas masa depan tidak terlepas dari peran aktif tenaga kerja atau pegawai yang memiliki kemampuan, kreativitas, inovatif dan bertanggung jawab dalam melaksanakan pekerjaannya berupaya mewujudkan sistem dan iklim pendidikan yang baik.

Pegawai Fakultas Ekonomi Universitas PGRI Palembang sebagai suatu unit kerja yang melaksanakan tugas pekerjaan, memerlukan sumber daya manusia yang disiplin tinggi, kepemimpinan yang kondusif. Hal ini sangat diperlukan untuk memberikan umpan balik dalam upaya meningkatkan kualitas kinerja pegawai dalam organisasi. Keberhasilan penyelenggaraan Pendidikan Perguruan Tinggi pada Universitas PGRI Palembang, tergantung pada peran aktif civitas akademika secara keseluruhan. Hal ini erat kaitannya dengan masalah sikap mental, tekad, semangat, ketaatan, disiplin, tanggung jawab dan keterampilan secara seluruh. Untuk itu perlu adanya kedisiplinan yang tinggi, komunikasi yang baik dan motivasi yang tinggi dalam menjalankan tugas untuk mencapai tujuan dalam suatu organisasi.

Kepuasan kerja mencerminkan perasaan seseorang terhadap pekerjaannya. Ini nampak dari sikap karyawan terhadap pekerjaan dan segala sesuatu di lingkungan kerjanya. Menurut Handoko (1998: 193) menjadi kewajiban setiap pemimpin perusahaan untuk menciptakan kepuasan kerja bagi para karyawannya, karena kepuasan kerja merupakan faktor yang diyakini dapat mendorong dan mempengaruhi semangat kerja karyawan agar karyawan dapat bekerja dengan baik dan secara langsung akan mempengaruhi prestasi karyawan. Seorang manajer juga dituntut agar memberikan suasana kerja yang baik dan menyenangkan, juga jaminan keselamatan kerja sehingga karyawan akan merasa terpuaskan.

Hasil dari pengamatan peneliti lakukan di Fakultas Ekonomi Universitas PGRI Palembang menunjukan bahwa kepuasan kerja pegawai belum optimal, hal ini terlihat dari hasil absensi pegawai Fakultas Ekonomi Universitas PGRI Palembang selama 12 (dua belas) bulan rata-rata kehadiran pegawai di bawah $100 \%$. Dari keterangan di atas dapat disimpulkan bahwa tingkat kepuasan kerja yang dirasakan oleh pegawai Fakultas Ekonomi belum optimal, karena masih ada beberapa indikator yang menyatakan tidak puas artinya seorang pimpinan masih belum memahami beberapa indikator yang seharusnya membuat bawahan puas. 
Berdasarkan uraian dari latar belakang di atas, maka penulis tertarik untuk mengadakan penelitian pada Fakultas Ekonomi Universitas PGRI Palembang dengan judul : " Pengaruh Disiplin, Budaya Kerja, dan Motivasi Terhadap Kepuasan Kerja Pegawai Pada Fakultas Ekonomi Universitas PGRI Palembang"

\section{B. Perumusan Masalah}

Berdasarkan pembatasan masalah di atas, maka dapat dirumuskan masalah sebagai berikut:

1. Apakah secara simultan terdapat pengaruh yang signifikan antara Disiplin, Budaya Kerja, dan Motivasi Terhadap Kepuasan Kerja Pegawai Pada Fakultas Ekonomi Universitas PGRI Palembang?

2. Apakah secara parsial terdapat pengaruh yang signifikan antara Disiplin, Budaya Kerja, dan Motivasi Terhadap Kepuasan Kerja Pegawai Pada Fakultas Ekonomi Universitas PGRI Palembang?

\section{TINJAUAN PUSTAKA}

\section{A. Kajian Teori}

1. Kepuasan Kerja

Kepuasan kerja adalah sikap umum terhadap pekerjaan seseorang yang menunjukkan perbedaan antara jumlah penghargaan yang di terima pekerja dan jumlah yang mereka yakini seharusnya mereka terima. Wibowo (2010 : 501). Sedangkan menurut Hasibuan, (2009 : 202). kepuasan kerja adalah sikap emosional yang menyenangkan dan mencintai pekerjaanya. Sikap ini tercermin oleh moral kerja, kedisiplinan dan prestasi kerja. Kepuasan kerja dinikmati dalam pekerjaan, luar pekerjaan dan kombinasi dalam dan luar pekerjaan. Sementara itu Rivai, (2007 : 249) menyatakan bahwa kepuasan kerja adalah penilaian dari pekerja tentang seberapa jauh pekerjaannya secara keseluruhan memuaskan kebutuhannya. Kepuasan kerja juga sikap umum yang merupakan hasil dari beberapa sikap, khusus terhadap faktor-faktor pekerjaan, penyesuaian diri, dan hubungan sosial individu diluar kerja.

Dari pendapat-pendapat diatas dapat disimpulkan bahwa kepuasan kerja adalah sikap seseorang terhadap pekerjaan yang menyenangkan dan memcintai pekerjaan serta harapan seseorang akan penghargaan yang diterimanya dari pekerjaan yang dilakukannya.

\section{Disiplin Kerja}

Kedisiplinan adalah fungsi keenam dari Manajemen Sumber Daya Manusia. Kedisiplinan merupakan fungsi operatif MSDM yang penting karena semakin baik disiplin pegawai, semakin tinggi prestasi kerja yang dapat dicapainya. Tanpa disiplin pegawai yang baik, sulit bagi organisasi perusahaan mencapai hasil optimal (Hasibuan, 2005: 193).

Sedangkan Fathoni (2006:126) menyatakan bahwa "kedisiplinan adalah kesadaran dan kesediaan seseorang mentaati semua peraturan perusahaan dan norma-norma sosial yang berlaku. Singodimedjo (2002:45) menyatakan bahwa "disiplin adalah sikap kesediaan dan kerelaan seseorang untuk memahami dan mentaati norma-norma peraturan yang berlaku disekitarnya".

Selanjutnya Moekijat (2005: 98) menyatakan bahwa "disiplin adalah kesanggupan menguasai diri yang diatur". Kemudian Siswanto (2006 : 24) menyatakan bahwa"disiplin kerja sebagai suatu sikap menghormati, menghargai, patuh dan taat terhadap peraturan-peraturan yang berlaku baik yang tertulis maupun tidak tertulis serta sanggup menjalankannya dan tidak 
mengelak menerima sanksi-sanksi apabila ia melanggar tugas dan wewenang yang diberikan kepadanya". Berdasarkan beberapa pengertian di atas dapat disimpulkan bahwa disiplin kerja diartikan sikap atau tingkah laku yang menunjukkan kesetiaan dan ketaatan seseorang atau sekelompok orang terhadap peraturan yang telah ditetapkan oleh instansi atau organisasinya baik yang tertulis maupun tidak tertulis sehingga diharapkan pekerjaan yang dilakukan efektif dan efesien.

\section{Budaya Kerja}

Budaya Kerja adalah suatu falsafah dengan didasari pandangan hidup sebagai nilai-nilai yang menjadi sifat, kebiasaan dan juga pendorong yang dibudayakan dalam suatu kelompok dan tercermin dalam sikap menjadi perilaku, cita-cita, pendapat, pandangan serta tindakan yang terwujud sebagai kerja Supriyadi dan Guno (2006 : 8).

Budaya kerja adalah suatu nilainilai yang menjadikan pedoman SDM untuk menghadapi permasalahanpermasalahan eksternal dan usaha penyesuaian integrasi ke dalam organisasi, sehingga masing-masing anggota organisasi harus memahami nilai-nilai yang ada dan bagaimana mereka harus bertindak dan berperilaku.

Budaya kerja ialah cara kerja yang berdasarkan suatu sistem nilai yang dipegang oleh setiap kakitangan dalam organisasi. Cara kerja yang diamalkan seperti itu sudah menjadi kebiasaan atau tradisi organisasi tersebut.

Nilai ialah sesuatu yang dipegang dan diterima oleh seluruh masyarakat dalam sesebuah organisasi. Jika apa yang dipegang itu adalah baik, maka nilai itu adalah baik dan positif. Jika tidak, ia adalah dianggap tidak baik dan negatif maka akan ditolak.

Budaya kerja juga ditentukan oleh sistem, prosedur dan struktur organisasi itu sendiri. Selain itu juga, budaya kerja memerlukan pemimpin yang berkualiti bagi menerajui sesebuah organisasi ke satu tahap yang dibanggakan. Budaya kerja yang mampu mewujudkan suasana kerja yang selesa dan sistematik berupaya menyumbang kepada peningkatan kualitas dan produktiviti kerja.

Selanjutnya budaya kerja dapat diartikan suatu falsafah yang didasari oleh pandangan hidup sebagai nilainilai yang menjadi sifat, kebiasaan dan kekuatan pendorong, membudaya dalam kehidupan suatu kelompok masyarakat atau organisasi, kemudian tercermin dari sikap menjadi perilaku, kepercayaan, cita-cita, pendapat dan tindakan yang terwujud sebagai "kerja" atau "bekerja". Waridin dan Masrurukhin (2006 : 43).

\section{Motivasi}

Secara umum motivasi pada dasarnya adalah suatu proses untuk mencoba mempengaruhi seseorang agar melakukan sesuatu yang kita inginkan. Dengan kata lain motivasi adalah dorongan dari luar terhadap seseorang agar mau melaksanakan sesuatu, dorongan (Driving Force) disini maksudnya adalah desakan yang alami untuk memuaskan kebutuhan hidup dan mempunyai kecenderungan untuk mempertahankan hidup.

Menurut Hasibuan (2006 : 323) motivasi adalah suatu proses dimana kebutuhan-kebutuhan mendorong seseorang untuk melakukan serangkaian kegiatan yang mengarah tercapainya tujuan tertentu. Liang Gie dalam Samsudin (2006 : 281) motivasi adalah pekerjaan yang dilakukan oleh manejer dalam memberikan inspirasi, 
semangat, dan dorongan kepada orang lain, dalam hal ini pegawainya, untuk mengambil tindakan-tindakan tertentu. Edwin B Flippo dalam Hasibuan (2007 : 143) motivasi adalah suatu keahlian, dalam mengarahkan pegawai dan organisasi agar mau bekerja secara berhasil, sehingga kenginan para pegawai dan tujuan organisasi sekaligus tercapai. Sedangkan menurut Bernerd Berelson dan Gary A. Steiner dalam Siswanto (2006 : 119) mendefinisikan motivasi sebagai keadaan kejiwaan dan sikap mental manusia yang memberikan energi, mendorong kegiatan (moves), dan mengarah atau menyalurkan perilaku ke arah mencapai kebutuhan yang memberikan kepuasan atau mengurangi ketidak seimbangan.

Dari beberapa pengertian tentang motivasi diatas, dapat diambil kesimpulan bahwa motivasi adalah sesuatu yang mendorong seseorang untuk melakukan suatu tindakantindakan untuk mencapai suatu tujuan yang telah ditetapkan.

\section{B. Hasil Penelitian Lain Yang Relevan}

1. Penelitian tentang Disiplin

Handoko Sanjaya (2008) dalam Penelitiannya tentang Hubungan Gaya Kepemimpinan dan Disiplin Kerja dengan Kinerja Pegawai PT. Exa Gaya Mandiri Solusi Palembang, dimana ia mengatakan bahwa terdapat hubungan Disiplin Kerja dengan Kinerja pegawai. Dimana Disiplin Kerja memiliki koofisien korelasi sebesar 0,748 maka dinyatakan bahwa setiap penambahan satusatuan jumlah Disiplin Kerja akan meningkat kinerja pegawai sebesar 0,748 .

2. Penelitian tentang Budaya Kerja Ida Wati Oktavia (2011) dalam Penelitiannya tentang hubungan
Pengaruh Gaya Kepemimpinan dan Budaya Kerja terhadap Kepuasan Kerja Pegawai Unit Pelaksana Teknis Dinas (UPTD) Indralaya Utara Ogan Ilir. Mengatakan bahwa terdapat hubungan Gaya kepemimpinan dan Budaya Kerja terhadap Kepuasan Kerja. Hasil penelitian diperoleh koefisien determinasi Variable (R2) 0,413, ini berarti $41,3 \%$ pariasi nilai skor produktivitas kerja sisanya $58,7 \%$ dijelaskan oleh faktor lain.

\section{Penelitian tentang Motivasi}

Surya Dewa Antaguna (2008) dalam Penelitiannya tentang hubungan Motivasi dan Komitmen Pegawai dengan Kinerja Pegawai PT. Thamrin Brothers Palembang, dimana ia mengatakan bahwa setiap penambahan satu satuan jumlah Motivasi akan meningkatkan kinerja pegawai sebasar 1,040 .

\section{Kerangka Berfikir}

Secara ringkas kerangka pemikiran yang mendasari penelitian ini diilustrasikan kedalam bagan berikut ini :

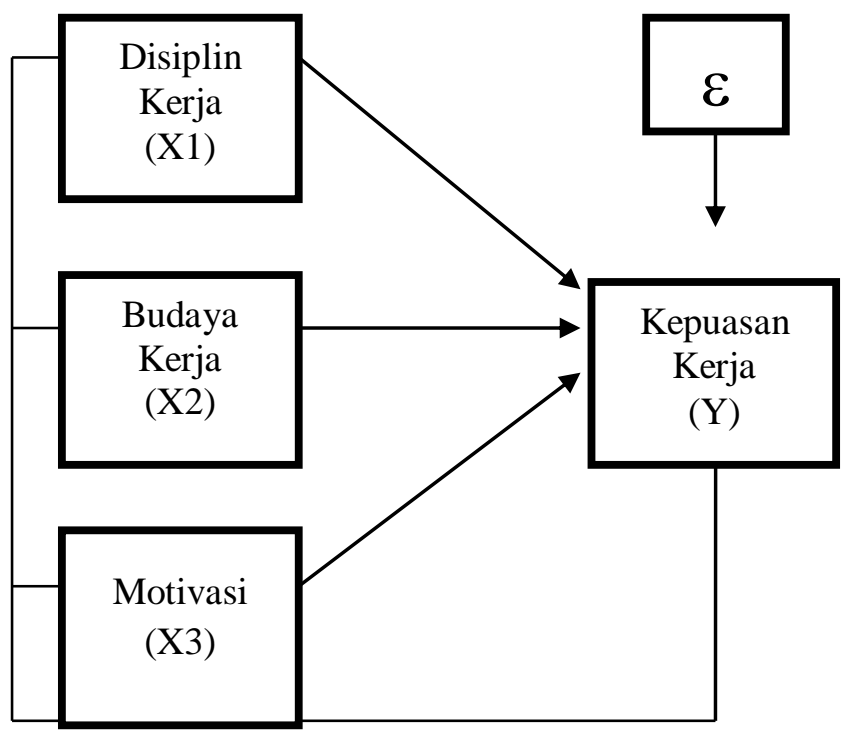

Gambar 1. Kerangka berfikir Penelitian 


\section{Hipotesis Penelitian}

Dari teori dan kerangka berfikir penelitian yang dikemukakan di atas, maka diambil dugaan sementara atau hipotesis sebagai berikut:

1. Diduga disiplin, budaya kerja dan motivasi secara simultan mempunyai pengaruh yang signifikan terhadap kepuasan kerja pegawai pada Fakultas Ekonomi Universias PGRI Palembang.

2. Diduga disiplin mempunyai pengaruh yang signifikan terhadap kepuasan kerja pegawai pada Fakultas Ekonomi Universias PGRI Palembang.

3. Diduga budaya kerja mempunyai pengaruh yang signifikan terhadap kepuasan kerja pegawai pada Fakultas Ekonomi Universias PGRI Palembang.

4. Diduga motivasi mempunyai pengaruh yang signifikan terhadap kepuasan kerja pegawai pada Fakultas Ekonomi Universias PGRI Palembang.

\section{METODE PENELITIAN}

\section{A. Populasi dan Teknik Sampling}

1. Populasi

Menurut Sugiyono (2010 : 61) populasi adalah wilayah generalisasi yang terdiri atas: objek atau subjek yang mempunyai kualitas tertentu yang ditetapkan oleh peneliti untuk dipelajari dan kemudian ditarik kesimpulannya. Populasi dalam penelitian ini adalah adalah sebanyak 33 orang.

\section{Teknik Sampling}

Sampel menurut Sugiyono (2010: 62) adalah bagian dari jumlah dan karakteristik yang dimiliki populasi tersebut. Selanjutnya Sugiyono mengatakan "Bila populasi besar dan peneliti tidak mungkin mempelajari semua yang ada pada populasi, misalnya karena keterbatasan dana, tenaga, dan waktu, maka peneliti dapat menggunakan sampel yang diambil dari populasi itu". Berdasarkan pendapat di atas maka pada penelitian ini akan menggunakan data populasi yaitu semua pegawai yang ada di Fakultas Ekonomi Universitas PGRI Palembang sebanyak 33 orang sebagai sampel penelitian ini baik untuk uji coba instrument maupun data penelitian dengan menggunakan sampling jenuh.

\section{B. Definisi Operasional Variabel}

1. Kepuasan Kerja Pegawai $(\mathrm{Y})$ Kepuasan kerja adalah sikap emosional yang menyenangkan dan mencintai pekerjaannya. Sikap ini dicerminkan moral kerja, kedisiplinan dan pretasi kerja. Kepuasan kerja dinikmati dalam pekerjaan, luar pekerjaan dan kombinasi dalam dan luar pekerjaan Hasibuan (2009:203), dengan indikator Pembayaran (Gaji, Upah), Promosi Jabatan, Penyeliaan/Supervisi, Rekan Kerja, dan Kondisi Kerja.

2. Variabel Disiplin $\left(\mathrm{X}_{1}\right)$

Disiplin kerja adalah sikap
atau tingkah lakur yang
menunjukkan kesetiaan dan
ketaatan seseorang atau
sekelompok orang terhadap peraturan yang telah ditetapkan oleh instansi atau organisasinya baik yang tertulis maupun tidak tertulis sehingga diharapkan pekerjaan yang dilakukan efektif dan efesien. Disiplin kerja dalam penelitian ini diukur dari disiplin waktu, disiplin peraturan dan disiplin tanggung jawab, dengan indikator disiplin waktu, disiplin peraturan dan disiplin tanggung jawab 
3. Variabel Budaya Kerja $\left(\mathrm{X}_{2}\right)$

Budaya kerja dapat diartikan suatu falsafah yang didasari oleh pandangan hidup sebagai nilainilai yang menjadi sifat, kebiasaan dan kekuatan pendorong, membudaya dalam kehidupan suatu kelompok masyarakat atau organisasi, kemudian tercermin dari sikap menjadi perilaku, kepercayaan, cita-cita, pendapat dan tindakan yang terwujud sebagai "kerja" atau "bekerja" Waridin dan Masrurukhin (2006 : 25), dengan indikator kedisiplinan, tanggung jawab, proaktif dan pengembangan karyawan.

4. Variabel Motivasi $\left(\mathrm{X}_{3}\right)$

Motivasi adalah sesuatu yang mendorong seseorang untuk melakukan suatu tindakantindakan untuk mencapai suatu tujuan yang telah ditetapkan. Motivasi dalam penelitian ini diukur dari lingkungan kerja, gaji yang adil, insentif, rasa aman, penghargaan dan perlakuan yang adil, dengan indikator lingkungan kerja, gaji yang adil, insentif, rasa aman, penghargaan dan perlakuan yang adil.

\section{Jenis dan Sumber Data}

Jenis data yang digunakan dalam penelitian ini adalah:

\section{Data Primer}

Data primer merupakan data yang dikumpulkan sendiri oleh perorangan atau langsung melalui obyeknya. Pengumpulan data ini biasanya dilakukan dengan membagikan kuesioner kepada obyek penelitian dan diisi secara langsung oleh responden.

\section{Data Sekunder}

Data sekunder adalah data yang diperoleh secara tidak langsung atau melalui media perantara. Data yang didapatkan dari arsip yang dimiliki organisasi/instansi, penelitian terdahulu, literatur, dan jurnal yang berhubungan dengan permasalahan yang diteliti.

\section{Metode Pengumpulan Data \\ 1. Kuisioner}

Yaitu daftar pertanyaan yang ditujukan kepada staf dan pegawai Fakultas Ekonomi Universitas PGRI Palembang yang mampu dan berwenang dalam memberikan jawaban yang diperlukan.

\section{Dokumentasi}

Dokumentasi ialah data yang berupa dokumen atau catatan tertulis, data yang didapat dari dokumentasi merupakan data untuk melengkapi hasil dari wawancara yang telah dilaksanakan/hasil wawancara dapat dipenuhi oleh data tersebut.

\section{E. Pengujian Instrumen Penelitian}

Agar instrumen penelitian valid dan reliable maka sebelum digunakan perlu diuji coba (pre test) terlebih dahulu. Yang dimaksud valid adalah instrumen sebagai alat ukur benarbenar mengukur apa yang diukur. Sedangkan reliable artinya instrumen sebagai alat ukur dapat memperoleh hasil ukur yang ajeg (konsisten) atau tetap asas.

Menurut Haryono, (2007: 22) menyatakan bahwa penelitian harus memenuhi persyaratan keabsahan dapat dipenuhi bila instrumen tersebut megukur sesuatu yang harus diukur. Dan prinsip keandalan dapat dipenuhi bila instrumen tersebut dapat menghasilkan data yang stabil dan konsisten serta tidak berfluktuasi dan terkontaminasi (bias) oleh waktu dan tempat. 


\section{Uji Validitas}

Validitas merupakan suatu alat yang digunakan untuk mengukur keshahihan, ketepatan, kecermatan suatu alat ukur dalam melakukan fungsi ukurnya. Suatu tes atau instrumen pengukuran dapat dikatakan mempunyai validitas tinggi apabila alat tersebut dapat mengukur atau memberikan hasil ukur yang sesuai dengan apa yang hendak diukur. Menurut Sugiyono (2010: 228) dalam pengujian validitas, untuk mencari harga korelasi dengan menggunakan rumus Korelasi Pearson Product Moment.

Kriteria pengujiannya dilakukan dengan cara membandingkan $r_{\text {hitung }}$ dengan $r_{\text {table }}$ pada taraf $a=0,05$, Jika hasil perhitungan ternyata $r_{\text {hitung }}>r_{\text {tabel }}$ maka butir instrument dianggap valid, sebaliknya jika $r_{\text {hitung }}<r_{\text {tabel }}$ maka dianggap tidak valid (invalid), sehingga instrumen tidak dapat digunakan dalam penelitian.

\section{Uji Reliabilitas}

Menurut Priyatno (2010: 97) reliabilitas digunakan untuk mengetahui konsistensi alat ukur, apakah alat pengukur yang digunakan dapat diandalkan dan tetap konsisten jika pengukuran tersebut diulang. Uji Reliabilitas yang di gunakan dalam penelitian ini adalah metode Cronbach's Alpha.

\section{F. Uji Asumsi Klasik}

Dalam analisis regresi perlu dilakukan pengujian asumsi klasik agar hasil analisis regresi dapat memenuhi kriteria best, linear dan supaya variabel independent sebagai estimator atas variabel dependent tidak bias. Uji asumsi klasik ini terdiri atas uji normalitas, uji heteroskedastik, dan uji multikolinearitas.

\section{a) Uji Normalitas Data}

Uji normalitas bertujuan untuk menguji salah satu asumsi dasar analisis regresi berganda, yaitu variabel-variabel independen dan dependen harus berdistribusi normal atau mendekati normal (Ghozali, 2006). Untuk menguji apakah datadata yang dikumpulkan berdistribusi normal atau tidak dapat dilakukan dengan metode grafik dan statistik. Metode grafik yang handal untuk menguji normalitas data adalah dengan melihat normal probability plot, dimana bila titik-titik yang menyebar disekitar garis diagonal serta penyebarannya mengikuti arah garis diagonal, maka data tersebut dapat dikatakan berdistribusi normal.

\section{b) Uji Multikolinearitas}

Menurut Priyatno (2010), uji multikolinearitas berguna untuk mengetahui ada atau tidaknya penyimpangan asumsi klasik multikolinearitas yaitu adanya hubungan linear antar variabel bebas, dalam model regresi yang baik seharusnya tidak terjadi korelasi antara variabel independen. Untuk mendeteksi adanya Multikolinearitas, maka dapat dilihat dengan Besaran nilai VIF (Variance Inflation Factor) dan Tolerance. Persamaan regresi yang bebas multikolinearitas adalah mempunyai nilai VIF disekitar angka 1 dan Mempunyai angka tolerance mendekati 1.

\section{c) Uji Heteroskedastisitas}

Menurut Prayitno (2010), uji heteroskedastisitas bertujuan menguji apakah dalam model regresi terjadi ketidaksamaan varians dari residual satu pengamatan ke pengamatan yang lain. Pemeriksaan terhadap gejala Heteroskedastisitas adalah dengan melihat pola diagram pencar yang dihasilkan dari selisih antara nilai $Y$ 
prediksi dengan $Y$ observasi. Jika diagram pencar yang ada membentuk pola-pola tertentu yang teratur maka regresi mengalami Heteroskedastisitas. Jika diagram pencar tidak membentuk pola atau acak maka regresi tidak mengalami gangguan Heteroskedastisitas.

\section{G. Teknik Analisis Data}

Dalam rangka menganalisis data penelitian dipergunakan analisis regresi linear berganda untuk mengetahui pengaruh variable disiplin $\left(X_{1}\right)$, budaya kerja $\left(X_{2}\right)$ dan motivasi $\left(X_{3}\right)$ terhadap kepuasan kerja pegawai (Y) baik secara parsial maupun secara bersama.

Koefisien determinasi pada intinya mengukur seberapa jauh kemampuan model dalam menerangkan variasi dependen (Ghozali, 2006:103). Koefisien determinasi $\left(\mathrm{R}^{2}\right)$ dimaksudkan untuk mengetahui tingkat ketepatan paling baik dalam analisis regresi, dimana hal yang ditunjukkan oleh besarnya koefisien determinasi $\left(R^{2}\right)$ antara 0 (nol) dan 1 (satu). Jika koefisien determinasi bernilai nol berarti variabel independen sama sekali tidak berpengaruh terhadap variable dependen. Dan jika koefisien determinasi semakin mendekati satu, maka dapat dikatakan bahwa variabel independen berpengaruh terhadap variabel dependen. Selain itu koefisien determinasi dipergunakan untuk mengetahui presentase perubahan variabel terikat $(\mathrm{Y})$ yang disebabkan oleh variabel bebas $(\mathrm{X})$.

\section{H. Uji Hipotesis Statistik}

Untuk mengetahui ada tidaknya pengaruh variabel bebas terhadap variabel terikat, maka dilakukan pengujian terhadap hipotesis yang diajukan dalam penelitian ini. Metode pengujian terhadap hipotesis, dilakukan secara parsial menggunakan uji $\mathrm{t}$ dan pengujian secara simultan menggunakan uji $\mathrm{F}$.

\section{Uji Signifikansi Simultan (Uji Statistik F)}

Dipergunakan untuk menguji nyata tidaknya pengaruh variabel bebas secara simultan terhadap variabel terikat (Ghozali, 2006 : 46).

\section{Uji Signifikansi Parsial (Uji} Statistik t)

Uji $t$ dipergunakan untuk mengetahui pengaruh antara variabel disiplin $\left(X_{1}\right)$, budaya kerja $\left(X_{2}\right)$ dan motivasi $\left(X_{3}\right)$ dengan kepuasan kerja pegawai (Y) secara parsial.

\section{PEMBAHASAN HASIL PENELITIAN}

\section{A. Pengujian Instrumen}

1. Uji Validitas

Dari hasil perhitungan uji validitas untuk ketiga variabel yaitu disiplin $\left(X_{1}\right)$, budaya kerja $\left(X_{2}\right)$, motivasi $\left(X_{3}\right)$ dan kepuasan kerja pegawai (Y) diperoleh nilai signifikan lebih kecil dari alpha 0,05 sehingga semua pertanyaan dinyatakan valid. Untuk penelitian selanjutnya ketiga variabel tersebut menggunakan semua butir pernyataan.

\section{Uji Reliabilitas}

\section{Tabel 1}

\section{Rekapitulasi Hasil Uji Reliabilitas}

\begin{tabular}{|c|l|c|}
\hline No & \multicolumn{1}{|c|}{ Variabel } & $\begin{array}{c}\text { Cronbach's } \\
\text { Alpha }\end{array}$ \\
\hline 1 & Disiplin kerja (X1 & 0,797 \\
\hline 2 & Budaya kerja (X2) & 0,790 \\
\hline 2 & Motivasi (X2) & 0,855 \\
\hline 3 & Kepuasan kerja (Y) & 0,862 \\
\hline \multicolumn{3}{|c|}{ Sumber: data primer yang diolah, 2015 }
\end{tabular}

Dilihat dari hasil pengujian data reliabilitas yang dilakukan dengan bantuan program SPSS versi 17.00, maka dapat disimpulkan untuk 
variabel disiplin kerja (X1), budaya kerja (X2), motivasi (X3) dan kepuasan kerja pegawai $(\mathrm{Y})$ memiliki Nilai Cronbach's Alpha $\geq 0,6$ pada taraf nyata alpha $=5 \%$, berarti semua item pertanyaan yang ada pada instrumen tersebut dinyatakan reliable dan dapat dijadikan sebagai alat ukur dalam analisis selanjutnya.

\section{Uji Multikolinieritas}

Tabel 2 Hasil Uji Multikolineritas

\begin{tabular}{|l|c|c|}
\hline \multirow{2}{*}{ Model } & \multicolumn{2}{|c|}{ Collinearity Statistics } \\
\cline { 2 - 3 } & Tolerance & VIF \\
\hline Disiplin kerja (X1) & 0,783 & 1,276 \\
Budaya kerja (X2) & 0,862 & 1,160 \\
Motivasi (X3) & 0,881 & 1,134 \\
\hline
\end{tabular}

Sumber: data primer yang diolah, 2015

Berdasarkan indikator nilai VIF dan tolerance yang dapat dilihat pada tabel di atas, dinyatakan bahwa model regresi dalam penelitian ini terbebas dari persoalan atau problem multikolinearitas, karena nilai VIF dan tolerance masing-masing dibawah dan diatas cut off value yang ditetapkan.

\section{Uji Heteroskedastisitas}

Scatterplot

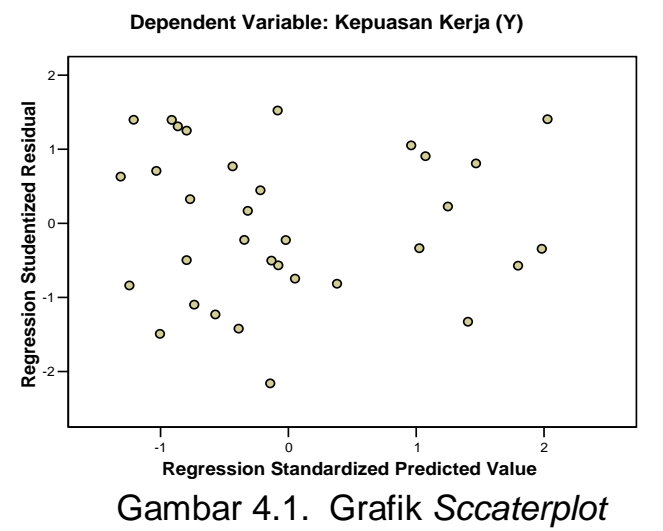

Berdasarkan Gambar di atas, nampak bahwa noktahnoktah terpencar dengan tidak membentuk pola seperti cerobong asap di sekitar garis diagonal (menyebar lalu menyempit atau sebaliknya), di atas dan di bawah angka 0 pada sumbu $Y$. Dinyatakan bahwa pada model regresi dalam penelitian ini terjadi homoskedastisitas daripada heteroskedastisitas.

\section{Uji Normalitas}

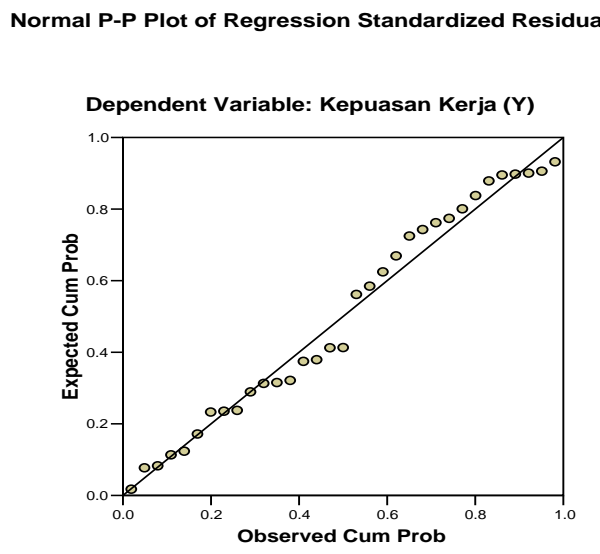

Gambar 2. Normal probability plot

Berdasarkan gambar di atas, nampak bahwa sebaran (pencaran) data berada di sekitar garis diagonal dan tidak ada yang terpencar jauh dari garis diagonal, sehingga asumsi normalitas dapat dipenuhi.

\section{B. ANALISIS DATA}

1. Analisis Regresi Berganda

\section{Tabel 3}

Analisis Regresi Variabel $\left(\mathrm{X}_{1}\right),\left(\mathrm{X}_{2}\right)$, $\left(X_{3}\right)$ dan $(Y)$

\begin{tabular}{|l|r|r|r|}
\hline \multirow{2}{*}{ Model } & \multicolumn{2}{|c|}{$\begin{array}{c}\text { Unstandardized } \\
\text { Coefficients }\end{array}$} & $\begin{array}{c}\text { Standardized } \\
\text { Coefficients }\end{array}$ \\
\cline { 2 - 4 } & \multicolumn{1}{|c|}{ B } & \multicolumn{1}{c|}{$\begin{array}{c}\text { Std. } \\
\text { Error }\end{array}$} & \multicolumn{1}{|c|}{ Beta } \\
\hline (Constant) & 1,390 & 5,690 & \\
Disiplin kerja &, 174 &, 078 &, 279 \\
Budaya kerja &, 426 &, 087 &, 591 \\
Motivasi &, 181 &, 081 &, 264 \\
\hline
\end{tabular}


Dari hasil perhitungan melalui program SPSS di atas, diperoleh nilai koefisien regresi untuk constanta $=1,390$, koefisien disiplin kerja $=0,174$, koefisien budaya kerja $=0,426$ dan koefisien motivasi $=0,181$. Sehingga persamaan regresi berganda dapat dituliskan sebagai berikut :

$$
\begin{aligned}
\hat{Y}= & 1,390+0,174 X_{1}+0,426 X_{2}+ \\
& 0,181 X_{3}+e
\end{aligned}
$$

Dimana :

1. Konstanta sebesar 1,390 menyatakan bahwa jika mengabaikan disiplin kerja, budaya kerja dan motivasi maka skor kepuasan kerja pegawai adalah 1,390.

2. Koefisien regresi $X_{1}$ sebesar 0,174 bernilai positif menyatakan bahwa setiap penambahan satu satuan skor disiplin kerja akan meningkatkan skor kepuasan kerja pegawai sebesar 0,174 dengan menjaga skor budaya kerja $\left(\mathrm{X}_{2}\right)$ dan motivasi $\left(\mathrm{X}_{3}\right)$ tetap/konstan.
3. Koefisien regresi $X_{2}$ sebesar 0,426 bernilai positif menyatakan bahwa setiap penambahan satu satuan skor budaya kerja akan meningkatkan skor kepuasan kerja pegawai sebesar 0,426 dengan menjaga skor disiplin kerja $\left(X_{1}\right)$ dan motivasi $\left(X_{3}\right)$ tetap/konstan.

4. Koefisien regresi $X_{3}$ sebesar 0,181 bernilai positif menyatakan bahwa setiap penambahan satu satuan skor motivasi akan meningkatkan skor kepuasan kerja pegawai sebesar 0,181 dengan menjaga skor disiplin kerja $\left(X_{1}\right)$ dan budaya kerja $\left(\mathrm{X}_{2}\right)$ tetap/konstan.

\section{Analisis Korelasi}

Koefisien korelasi ini untuk mengukur seberapa besar tingkat keeratan hubungan atau asosiasi yang terjadi antara baik variabel bebas secara parsial maupun variabel bebas secara bersamasama dengan variabel terikat.

Tabel 4

Analisis Korelasi Secara Simultan

\begin{tabular}{|l|l|r|r|r|}
\hline Model & $\mathrm{R}$ & $\begin{array}{c}\mathrm{R} \\
\text { Square }\end{array}$ & $\begin{array}{c}\text { Adjusted } \mathrm{R} \\
\text { Square }\end{array}$ & $\begin{array}{c}\text { Std. Error of } \\
\text { the Estimate }\end{array}$ \\
\hline 1 &, $799(\mathrm{a})$ &, 639 &, 601 & 2,450 \\
\hline
\end{tabular}

Berdasarkan hasil perhitungan melalui program SPSS dapat di intepretasikan sebagai berikut :

a. Pada Model Summary diperoleh nilai $R=0,799$ yang berarti bahwa hubungan atau tingkat asosiasi variabel bebas yaitu disiplin kerja, budaya kerja dan motivasi dengan variabel terikat yaitu kepuasan kerja pegawai adalah kuat dan positif. b. Angka $R$ Square (nilai koefisien determinasi $\left(R^{2}\right)$ sebesar 0,639 memberikan makna bahwa secara simultan atau serentak ketiga variabel bebas yaitu variabel disiplin kerja, budaya kerja dan motivasi mampu menjelaskan perubahan terhadap variabel kepuasan kerja pegawai sebesar 63,9\%, sedangkan sisanya dijelaskan oleh variabel-variabel lain yang 
tidak termasuk dalam penelitian ini atau error (e).

\section{Pengujian Hipotesis}

Pengujian hipotesis dimaksudkan untuk mengetahui apakah hipotesis penelitian yang diajukan ditolak atau diterima pada tingkat signifikan tertentu. Pada penelitian ini dilakukan analisis regresi untuk mengetahui apakah kedua variabel bebas yaitu disiplin kerja $\left(X_{1}\right)$, budaya kerja $\left(X_{2}\right)$ dan motivasi $\left(X_{3}\right)$, secara parsial (sendiri-sendiri) dan secara simultan

(bersama-sama) berpengaruh signifikan dan positif terhadap kepuasan kerja pegawai Pada Fakultas Ekonomi Universitas PGRI Palembang.

Pengujian untuk mengetahui ada tidaknya pengaruh dari masing-masing variabel bebas dengan variabel terikat secara parsial dilakukan dengan uji-t, sedangkan untuk mengetahui ada tidaknya pengaruh dari variabel bebas dengan variabel terikat secara simultan dilakukan melalui uji-F.

\section{Uji Signifikansi Simultan (Uji Statistik F)}

Tabel 5

Analisis Uji Hipotesis Secara Simultan

\begin{tabular}{|ll|r|r|r|r|c|}
\hline \multicolumn{2}{|c|}{ Model } & \multicolumn{1}{c|}{$\begin{array}{c}\text { Sum of } \\
\text { Squares }\end{array}$} & \multicolumn{1}{c|}{ df } & \multicolumn{1}{c|}{$\begin{array}{c}\text { Sean } \\
\text { Square }\end{array}$} & \multicolumn{1}{c|}{ F } & Sig. \\
\hline 1 & Regression & 307,778 & 3 & 102,593 & 17,089 &, $000(\mathrm{a})$ \\
& Residual & 174,101 & 29 & 6,003 & & \\
Total & 481,879 & 32 & & & \\
\hline
\end{tabular}

Dari hasil hasil perhitungan diperoleh nilai taraf signifikansi sebesar 0,000 atau signifikansi yang diperoleh lebih kecil dari $\alpha=$ 0,05 , artinya $\mathrm{H}_{0}$ ditolak, $\mathrm{H}_{\mathrm{a}}$ diterima. Hal ini dapat diartikan terdapat pengaruh yang signifikan dan positif disiplin kerja, budaya kerja dan motivasi secara bersamasama terhadap kepuasan kerja pegawai Pada Fakultas Ekonomi Universitas PGRI Palembang.

\section{Uji Signifikansi Parsial (Uji Statistik t)}

Tabel 6

\section{Analisis Uji Hipotesis Secara Parsial}

\begin{tabular}{|c|c|c|c|c|c|}
\hline \multirow[b]{2}{*}{ Model } & \multicolumn{2}{|c|}{$\begin{array}{c}\text { Unstandardized } \\
\text { Coefficients }\end{array}$} & \multirow{2}{*}{$\begin{array}{c}\text { Standardized } \\
\text { Coefficients } \\
\text { Beta }\end{array}$} & \multirow[t]{2}{*}{$\mathrm{t}$} & \multirow[t]{2}{*}{ Sig. } \\
\hline & B & $\begin{array}{l}\text { Std. } \\
\text { Error }\end{array}$ & & & \\
\hline $\begin{array}{ll}1 & \text { (Constant) }\end{array}$ & 1,390 & 5,690 & & ,244 & 809 \\
\hline Disiplin Kerja (X1) & , 174 & 078 & ,279 & 2,216 & ,035 \\
\hline Budaya Kerja (X2) & ,426 & ,087 & ,591 & 4,916 & ,000 \\
\hline Motivasi (X3) & , 181 & ,081 & ,264 & 2,224 & ,034 \\
\hline
\end{tabular}


a. Pengaruh disiplin kerja $\left(\mathrm{X}_{1}\right)$ dengan kepuasan kerja pegawai $(\mathrm{Y})$

Dari hasil perhitungan tabel diatas terilihat bahwa pada kolom signifikansi untuk baris disiplin kerja diperoleh 0,035 atau signifikansi yang diperoleh lebih kecil dari $\alpha=0,05$, artinya $\mathrm{H}_{0}$ ditolak, $\mathrm{H}_{\mathrm{a}}$ diterima. Hal ini dapat diartikan terdapat pengaruh yang signifikan dan positif disiplin kerja terhadap kepuasan kerja pegawai Pada Fakultas Ekonomi Universitas PGRI Palembang.

b. Pengaruh budaya kerja $\left(\mathrm{X}_{2}\right)$ dengan kepuasan kerja pegawai $(\mathrm{Y})$

Dari hasil perhitungan tabel diatas terilihat bahwa pada kolom signifikansi untuk baris budaya kerja diperoleh $\quad 0,000$ atau signifikansi yang diperoleh lebih kecil dari $\alpha=0,05$, artinya $\mathrm{H}_{0}$ ditolak, $\mathrm{H}_{\mathrm{a}}$ diterima. Hal ini dapat diartikan terdapat pengaruh yang signifikan dan positif budaya kerja terhadap kepuasan kerja pegawai Pada Fakultas Ekonomi Universitas PGRI

Palembang.

c. Pengaruh motivasi $\left(X_{3}\right)$ dengan kepuasan kerja pegawai $(Y)$

Dari hasil perhitungan tabel diatas terilihat bahwa pada kolom signifikansi untuk baris motivasi diperoleh 0,034 atau signifikansi yang diperoleh lebih kecil dari $\alpha=0,05$, artinya $\mathrm{H}_{0}$ ditolak, $\mathrm{H}_{\mathrm{a}}$ diterima. Hal ini dapat diartikan terdapat pengaruh yang signifikan dan positif motivasi terhadap kepuasan kerja pegawai Pada Fakultas Ekonomi Universitas PGRI Palembang.

\section{KESIMPULAN DAN SARAN}

\section{A. Kesimpulan}

Berdasarkan hasil analisis pengaruh dapat disimpulkan :

1. Secara bersama-sama atau simultan terdapat pengaruh yang positif dan signifikan disiplin kerja, budaya kerja dan motivasi terhadap kepuasan kerja pegawai Pada Fakultas Ekonomi Universitas PGRI Palembang, hal ini berarti apabila ada peningkatan dalam disiplin kerja, budaya kerja dan motivasi maka kepuasan kerja pegawai akan meningkat.

2. Bahwa secara parsial terdapat pengaruh yang positif dan signifikan disiplin kerja terhadap kepuasan kerja pegawai Pada Fakultas Ekonomi Universitas PGRI Palembang, artinya apabila ada peningkatan dalam disiplin kerja maka kepuasan kerja pegawai juga akan meningkat.

3. Secara parsial juga terdapat pengaruh yang positif dan signifikan budaya kerja terhadap kepuasan kerja pegawai Pada Fakultas Ekonomi Universitas PGRI Palembang, hal ini mengandung makna bahwa apabila ada peningkatan dalam budaya kerja maka kepuasan kerja pegawai juga akan meningkat. 
4. Secara parsial juga terdapat pengaruh yang positif dan signifikan motivasi terhadap kepuasan kerja pegawai Pada Fakultas Ekonomi Universitas PGRI Palembang, hal ini mengandung makna bahwa apabila ada peningkatan dalam motivasi maka kepuasan kerja pegawai juga akan meningkat.

\section{B. Implikasi}

Berdasarkan kesimpulan di atas, dapat diimplikasikan sebagai berikut:

1. Upaya meningkatkan disiplin kerja adalah dengan penyusunan jadwal kegiatan dan pelaksanaan program sesuai jadwal dan adanya panduan teknis setiap pelaksanaan kegiatan yang akan menciptakan keteraturan pelaksanaan kegiatan sesuai tujuan, target dan sasaran yang telah ditetapkan.

2. Upaya meningkatkan budaya kerja adalah dengan pendekatan-pendekatan melalui tindakan manajemen puncak dan proses sosialisasi, sehingga dapat menumbuh kembangkan dengan subur budaya kerja di kalangan pegawai.

3. Upaya meningkatkan motivasi adalah dengan memberikan pujian kepada pegawai selaku bawahan jika pekerjaannya selesai dengan baik sehingga terciptanya semangat yang tinggi untuk berprestasi dan mengarahkan pegawai untuk bekerja dengan sebaik-baiknya untuk pencapaian sasaran lembaga, sehingga tercipta suasana kerja yang kondusif.

\section{Saran}

1. Pimpinan

harus mempertimbangkan pemberian penghargaan kepada pegawai yang berprestasi maupun yang loyal kepada lembaga, sehingga dapat mendorong kepuasan kerja pegawai.

2. Pimpinan juga harus mempertimbangkan pemberian sanksi kepada pegawai yang melalaikan tugas.

3. Diharapkan setiap pegawai mematuhi jadwal kehadiran, dan diharapkan pimpinan terus mengingatkan pegawai untuk hadir tepat waktu sesuai dengan jadwal.

4. Diharapkan kepuasan kerja yang telah dicapai pada saat ini dapat dipertahankan dan lebih ditingkatkan lagi menjadi lebih optimal dengan kerjasama yang baik antara pimpinan dan para pegawai yang menjadi bawahannya.

\section{DAFTAR PUSTAKA}

Arikunto, Suharsimi. 1997. Prosedur Penelitian. Penerbit Rineka Cipta. Jakarta.

Davis, Keith dan Newstrom. 2000. Perilaku Dalam Organisasi, Edisi Ketujuh, Penerbit Erlangga, Jakarta

Dewi, Sari. 2004. Tesis: Pengaruh Kepemimpinan, Motivasi, Komunikasi, dan Kondisi Fisik Tempat Kerja Terhadap Semangat Kerja Karyawan (Studi Kasus pada Karyawan Produksi Divisi Blow PT Arisa Mandiri Pratama Demak). Program Studi Magister Manajemen Universitas Diponegoro. Semarang. (tidak untuk dipublikasikan).

Fathoni, Abdurrahmat. 2006. Manajemen Sumber Daya 
Manusia. Rineka Cipta. Jakarta.

Ghozali, Imam. 2006. Aplikasi Analisis Multivariat dengan program SPSS. Cetakan Kedua. Badan Penerbit Universitas Diponegoro. Semarang.

Gie, The Liang. 2000. Administrasi Perkantoran. Modern Liberty. Yogyakarta.

Gorda, I Gusti Ngurah. 2006. Manajemen Sumber Daya Manusia (MSDM). Penerbit Astabrata Bali. Denpasar.

Gunawan, Indra. 2000. Tesis: Analisis Motivasi dan Kondisi Kerja dalam Hubungannya dengan Semangat Karyawan Bagian Produksi pada PT Maju Jaya Sarana Grafika Semarang. Program Studi Magister Manajemen Universitas Diponegoro. Semarang. (tidak untuk dipublikasikan).

Handoko, T. Hani. 2002. Manajemen. Edisi Kedua. Penerbit BPFE. Yogyakarta.

Haryono, Siswoyo. 2007. Statistika Penelitian Manajemen dengan Program SPSS. Edisi Pertama. Jakarta.

Hasibuan Melayu. S. P. 2005. Manajemen Dasar, Pengertian dan Masalah. Penerbit Bumi Aksara. Jakarta.

Hasibuan, Melayu S. P. 2007. Manajemen Sumber Daya Manusia (MSDM). Bumi Aksara. Jakarta.

Komarudin. 2002. Pengadaan Personalia. Penerbit Rajawali Press. Jakarta.

Mangkunegara, Anwar Prabu. 2008. Evaluasi Kinerja SDM. PT Remaja Rosdakarya. Bandung.

Martoyo, Susilo. 2007. Penilaian Produktivitas Kerja. Gramedia Pustaka Utama. Jakarta.
Moekijat. 1995. Manajemen Personalia dan Sumber Daya Manusia. CV. Mandar Maju. Bandung . 2002. Tata Laksana Kantor (Manajemen Perkantoran). Cetakan Ke-8. Penerbit CV. Mandar Maju. Bandung.

$\begin{array}{lr}\text { Kepegawaian. } & \text { Manajemen } \\ \text { Alumni. Bandung. } & \text { Penerbit }\end{array}$

Nawawi, Hadari. 2001. Manajemen Sumber Daya Manusia. Bumi Aksara. Jakarta.

Nitisemito, Alex S. 2002. Manajemen Personalia. Cetakan Kesembilan. Edisi Ketiga. Penerbit Ghalia Indonesia. Jakarta.

Ningrat, Soewarno Handoyo, 1980. Pengantar IImu Studi Administrasi dan Manajemen, CV Haji Masagung. Jakarta.

Priyatno, Duwi. 2010. Paham Analisa Statistik Data dengan SPSS. Mediakom Remaja Rosdakarya. Yogyakarta

Robbins dan Coulter. 2002. Management. 7th edition. Prentice Hall, Inc., New Jersey.

Sastrohadiwiryo, Siswanto B. 2003. Manajemen Tenaga Kerja Indonesia Pendekatan Adminstratif dan Operasional. Bumi Aksara. Jakarta.

Sihombing, Umberto, 2004. Pengaruh Keterlibatan Dalam Pengambilan Keputusan, Penilaian pada Lingkungan Kerja dan Motivasi Berprestasi Terhadap Kepuasan Kerja Pamong Praja, htpp://www.dupdiknas.go.id, diakses 24 Juni 2013.

Singadimedjo, Markum. 2002. Manajemen Sumber Daya Manusia (MSDM). Edisi Ketiga. Cetakan Kedua. 
Penerbit STIE YKPN. Yogyakarta.

Siswanto, H. B. 2006. Pengantar Manajemen. Penerbit Bumi Aksara.

Strauss dan Sayles. 1999. Perilaku Organisasi. Penerbit Salemba Empat. Jakarta.

Sugiyono. 2010. Statistika Untuk Penelitian. Cetakan Ke-16. CV Alfabeta. Bandung.

Sutrisno, Eddy. 2010. Manajemen Sumber Daya Manusia (MSDM). Kencana Prenada Media Group. Jakarta.

Supardi dan Anwar, Syaiful. 2002. Dasar-dasar Perilaku Organisasi. Penerbit UII Press. Yogyakarta.

Suryadhana, N. A. 2012. Tesis: Analisis Pengaruh Kepemimpinan, Komunikasi, dan Motivasi Terhadap Kepuasan Kerja dan Implikasinya Terhadap Disiplin Kerja Pegawai pada PT Taspen (Persero) Kantor Cabang Utama Semarang. Program Studi Magister Manajemen Universitas Diponegoro. Semarang. (tidak untuk dipublikasikan).

Susilo. 2004. Tesis: Analisa Pengaruh Kepemimpinan dan Kepuasan Kerja Terhadap Motivasi Kerja dan Implikasinya Terhadap Disiplin Kerja Pegawai pada Kantor Bappeda Kabupaten Pati. Program Studi Magister Manajemen Universitas Diponegoro. Semarang. (tidak untuk dipublikasikan).

Thoha, Miftah. 2003. Kepemimpinan dalam Manajemen Suatu Pendekatan Perilaku. Cetakan Kesembilan. Penerbit PT Raja Grafindo Persada. Jakarta.

Triguno. 2007. Budaya Kerja: Menciptakan Lingkungan Yang
Kondusif Untuk Meningkatkan Produktivitas Kerja. PT Golden Trayon Press. Jakarta.

Umar, Husien. 2005. Riset Sumber Daya Manusia dalam Organisasi. Edisi Revisi dan Perluasan. Penerbit PT Gramedia Pustaka Utama. Jakarta.

Wahjosumidjo. 2002. Kepemimpinan Kepala Sekolah (Tinjauan Teori dan Permasalahannya). Penerbit Raja Grafindo Persada. Jakarta.

Wardhani, Laksmi. 2005. Tesis: Analisis Hubungan Disiplin Kerja, Kompensasi, dan Lingkungan Kerja Terhadap Produktivitas Kerja pada Pegawai Negeri Sipil Direktorat Jenderal Kekuatan Pertahanan Departemen Pertahanan. Pascasarjana UPN. Jakarta. (tidak untuk dipublikasikan).

Wexley, Kenneth N., dan Yuki, Gary A. 2003. Perilaku Organisisasi dan Psikologi Personalia. Penerbit Rineka Cipta. Jakarta. 